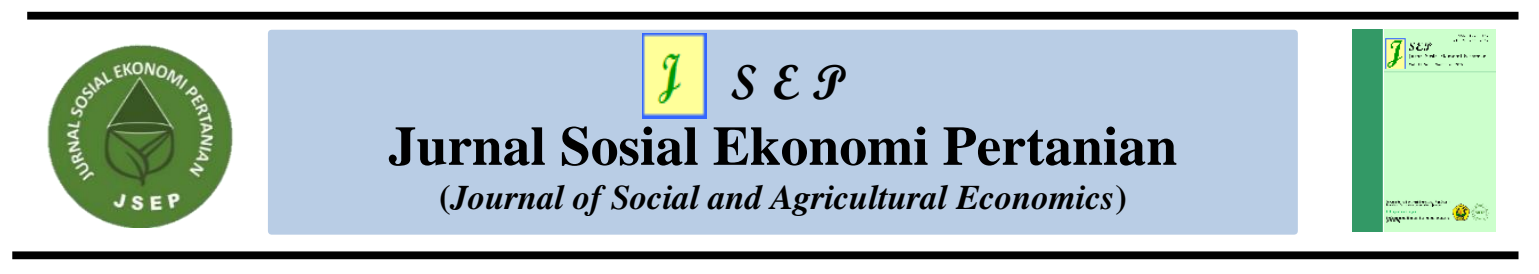

\title{
ANALISIS INVESTASI DAN KONTRIBUSI SEKTOR PERTANIAN \\ TERHADAP PEREKONOMIAN KABUPATEN MERANGIN PROVINSI JAMBI DENGAN MENGGUNAKAN PENDEKATAN ICOR
}

\section{ANALYSIS OF INVESTMENT AND AGRICULTURAL SECTOR CONTRIBUTIONS TO THE ECONOMY OF MERANGIN JAMBI PROVINCE USING ICOR APPROACHES}

\author{
Suandi $^{1 *}$, Arman Delis ${ }^{2}$ \\ ${ }^{1}$ Jurusan Agribisnis Fakultas Pertanian Universitas Jambi \\ ${ }^{2}$ Jurusan Ekonomi Pembangunan Fakultas Ekonomi dan Bisnis Universitas Jambi \\ *email: suandi_pertanian@unja.ac.id
}

\begin{abstract}
The research objective: (1) analyzing the investment and economics of Merangin Regency, (2) analyzing the contribution of the agricultural sektor to the economics of Merangin Regency, Jambi Province. The data used are series data from 2010-2014. Data were analyzed through the Incremental Capital Output Ratio (ICOR) approach. The results showed that during the 2011-2014 period, the largest investment was made in the agricultural sektor which reached 37.45 percent, then followed by the trade sektor and the manufacturing sektor, respectively 28.00 and 16.80 percent. The average ICOR rate for the period 2010 2014 was 9.41. The 2015 ICOR score is better than the previous year's ICOR value. The agricultural sektor has the lowest ICOR and is followed by the transportation sektor; construction; finance; and the service sektor so that the agricultural sektor has a positive and efficient impact on investing. The analysis shows that the agricultural sektor has a contribution to the economic of Merangin Regency.
\end{abstract}

Keywords: agricultural sector, contribution, ICOR, investment, regional economic

\begin{abstract}
ABSTRAK
Tujuan penelitian: (1) menganalisis investasi dan perekonomian Kabupaten Merangin, (2) menganalisis kontribusi sektor pertanian terhadap perekonomian Kabupaten Merangin. Data yang dibutuhkan dalam menganalisis investasi dan perekonomian Kabupaten Merangin adalah data sekunder yang mencakup informasi ekonomi secara sektoral pada periode waktu 2010-2014. Data dianalisis melalui pendekatan Incremental Capital Output Ratio (ICOR). Hasil penelitian menunjukkan bahwa selama periode 2011-2014, investasi terbesar dilakukan pada sektor pertanian yaitu mencapai 37,45 persen, kemudian diikuti sektor perdagangan dan sektor industri pengolahan, masing-masing 28,00 dan 16,80 persen. Rata-rata angka ICOR pada periode 2010-2014 sebesar 9.41. Nilai ICOR tahun 2015 lebih baik dari nilai ICOR tahun sebelumnya. Sektor pertanian memiliki ICOR terendah dan diikuti sektor pengangkutan; konstruksi; keuangan; dan sektor jasa sehingga sektor pertanian memiliki dampak positif dan efisien dalam berinvestasi. Hasil analisis menunjukkan bahwa sektor pertanian memiliki kontribusi terhadap perekonomian Kabupaten Merangin.
\end{abstract}

Kata kunci: ekonomi regional, kontribusi, ICOR, investasi, sektor pertanian

How to Cite: Suandi, \& Delis, A. (2020). Analisis Investasi dan Kontribusi Sektor Pertanian terhadap Perekonomian Kabupaten Merangin Provinsi Jambi dengan Menggunakan Pendekatan ICOR. JSEP: Jurnal Sosial Ekonomi Pertanian, 13(2): 112-124. 


\section{PENDAHULUAN}

Pertumbuhan ekonomi Kabupaten Merangin dalam selang waktu (2010-2013) mencapai 6,95 per tahun (Badan Pusat Statistik Kabupaten Merangin, 2015). Pertumbuhan tertinggi dalam periode tersebut terjadi pada tahun 2010 yang mencapai 7,85 persen, akan tetapi laju pertumbuhan tersebut cenderung menurun dalam tahun berikutnya menjadi 7,02 persen (2011), 6,47 persen (2012), dan 6,45 persen pada tahun 2013. Angka-angka ini lebih rendah dari laju pertumbuhan ekonomi Provinsi Jambi yang tercatat sebesar 7,76 persen per tahun pada periode yang sama (Badan Pusat Statistik Provinsi Jambi, 2015). Jika diamati pergerakannya dalam periode tersebut, pertumbuhan ekonomi Provinsi Jambi justru meningkat dari 6,84 persen (2010) menjadi 6,93 persen (2011) dan bahkan naik mencapai 8,69 persen (2012) sebelum turun kembali menjadi 8,59 persen (2013). Ini berarti pola pergerakan laju pertumbuhan ekonomi Kabupaten Merangin berkebalikan dengan pertumbuhan ekonomi Provinsi Jambi.

Menurut Laporan Badan Pusat Statistik Provinsi Jambi (2015), laju pertumbuhan ekonomi Kabupaten Merangin menempati peringkat ke-6 dari rata-rata pertumbuhan ekonomi seluruh kabupaten/kota di Provinsi Jambi. Laju pertumbuhan ekonomi Kabupaten Merangin selama periode 2010-2014 tergolong lambat. Oleh karena itu, perlu dicermati lebih lanjut perkembangan laju pertumbuhan ekonomi tersebut sehingga dapat diidentifikasi penyebabnya dan dapat dicarika solusi untuk mengatasinya agar tingkat kesejahteraan masyarakat dapat dipertahankan ataupun ditingkatkan pada periode berikutnya.

Penyebab lambatnya laju pertumbuhan ekonomi Kabupaten Merangin adalah keterbatasan sumber dana investasi dan tingkat efisiensi penggunaan barang modal yang merupakan komponen utama pendongkrak laju pertumbuhan ekonomi. Oleh sebab itu, analisis kebutuhan investasi untuk sektor-sektor ekonomi sangat diperlukan, agar setiap Rupiah yang diinvestasikan dapat diperhitungkan hasilnya dalam upaya mencapai laju pertumbuhan ekonomi yang telah ditargetkan. Seperti diungkapkan oleh Sulistiawati (2012) bahwa investasi berpengaruh signifikan dan mempunyai hubungan yang positif perekonomian nasional terutama penyerapan tenaga kerja. Hasil penelitian ini mengindikasikan bahwa kenaikan investasi akan diikuti dengan kenaikan pada penyerapan tenaga kerja provinsi di Indoensia.

Badan Pusat Satistik (BPS) Indonesia melaporkan bahwa jumlah tenaga kerja yang terlibat disektor pertanian sebesar 31,87 persen dari total tenaga kerja Indonesia (Badan Pusat Statistik Indonesia, 2019). Berdasarkan data tersebut maka peran Investasi sektor pertanian terhadap perekonomian daerah sangat penting diadakan. Hal ini sejalan dengan penelitian di Daerah Istimewa Yogyakarta (DIY) bahwa sektor pertanian sebagai salah satu sektor prioritas untuk investasi karena mempunyai ICOR terendah. Demikian pula berdasarkan serapan tenaga kerja, sektor pertanian masih menjadi tumpuan prioritas utama untuk investasi (Badan Pusat Statistik dan Badan Perencanaan Pembangunan Derah Daerah Istimewa Yogyakarta, 2013). Menurut Sayifullah \& Emmalian (2018) bahwa tenaga kerja sektor pertanian dan pengeluaran pemerintah (investasi) sektor pertanian secara bersama-sama berpengaruh signifikan terhadap PDB sektor pertanian. Berdasarkan logika pemikiran demikian, dipandang perlu untuk melakukan analisis Incramental Capital Output Ratio (ICOR) dan kontribusi sektor pertanian terhadap peningkatan perekonomian daerah. Tujuan penelitian (1) menganalisis investasi dan perekonomian Kabupaten Merangin, dan (2) menganalisis kontribusi sektor pertanian terhadap perekonomian Kabupaten Merangin. 


\section{METODE PENELITIAN}

Data yang dibutuhkan dalam penyusunan perhitungan ICOR dan analisis kebutuhan investasi Kabupaten Merangin adalah data sekunder yang mencakup data utama dan data pendukung. Data utama mencakup informasi ekonomi secara sektoral untuk periode waktu 2010-2014. Data tersebut meliputi: (1) Produk Domestik Regional Bruto (PDRB) Kabupaten Merangin dan Provinsi Jambi Atas Dasar Harga Konstan Menurut Lapangan Usaha yang diperoleh dari seri publikasi PDRB Kabupaten Merangin oleh Badan Pusat Statistik (BPS) Kabupaten Meranugin, (2) Data Investasi swasta domestik berfasilitas atau Penanaman Modal Dalam Negeri (PMDN) per sektor ekonomi yang diperoleh dari Badan Penanaman Modal Daerah persektor, (3) Data Investasi swasta domestik berfasilitas atau Penanaman Modal Dalam Negeri (PMDN) dan Data Investasi swasta Asing berfasilitas atau Penanaman Modal Asing (PMA) per sektor ekonomi yang diperoleh dari Badan Penanaman Modal Daerah, (4) Kredit investasi yang disalurkan perbankan persektor ekonomi diperoleh dari Bank Indonesia Jambi yang dipublikasikan dalam bentuk Seri Statistik Ekonomi dan Keuangan Daerah (SEKDA) Provinsi Jambi, (5) Kredit UMKM yang disalurkan perbankan per sektor ekonomi diperoleh dari Bank Indonesia Jambi dalam bentuk Seri Statistik Ekonomi dan Keuangan Daerah (SEKDA) Provinsi Jambi, (6) Realisasi APBD Kabupaten Merangin 2010-2014 berupa belanja langsung dan belanja modal persektor ekonomi. Analisis data dimulai dengan melakukan sortasi dan "coding". Kemudian dilanjutkan analisis data secara deskriptif dengan menggunakan tabel frekuensi tunggal untuk data kependudukan, ketenagakerjaan, dan data perekonomian Kabupaten Merangin. Untuk menganalisis data tentang Keunggulan Daerah dan Kebutuhan Investasi dilakukan dengan cara: (1) Location Qoutient (LQ), (2) Tipologi Klassen, dan (3) Incremental Capital Output Ratio (ICOR). ICOR merupakan sebuah koefisien yang digunakan untuk mengetahui berapa kebutuhan investasi baru yang dibutuhkan untuk menaikkan/menambah satu unit output (Harrod dan Evsey Domar: Badan Pusat Statistik dan Badan Perencanaan Pembangunan Derah Daerah Istimewa Yogyakarta, 2013). Besaran ICOR diperoleh dengan membandingkan besarnya tambahan kapital dengan tambahan output. ICOR tersebut digunakan untuk mengukur tingkat efisiensi dari suatu investasi. Selain itu juga dapat dilihat terjadinya inefficiency dalam investasi, yaitu bila koefisien ICOR bernilai negatif atau nilai relatif besar.

\section{HASIL DAN PEMBAHASAN Laju Pertumbuhan Ekonomi}

Menurut Laporan Badan Pusat Statistik Kabupaten Merangin (2015), perekonomian Kabupaten Merangin didominasi sektor pertanian yaitu mencapai 49,71 persen terhadap PDRB. Sektor pertanian merupakan lapangan usaha utama yang menjadi sumber penghidupan masyarakat Kabupaten Merangin. Tenaga kerja sektor pertanian mempunyai hubungan yang positif dan signifikan dalam meningkatkan Produk Domestik Regional Bruto (PDRB) (Sayifullah \& Emmalian, 2018). Namun, sebagian besar dari komoditas-komoditas pertanian tersebut belum dimanfaatkan lebih lanjut dalam aktivitas industri. Penyumbang terbesar kedua adalah sektor perdagangan besar dan eceran yang mencapai 11,05 persen. Aktivitas perdagangan tersebut berupa perdagangan eceran yang bersumber dari komoditas pertanian. Data ini mengindikasikan bahwa pengembangan aktivitas ekonomi yang bergerak di luar sektor pertanian bersinergi dengan aktivitas pertanian, terutama perkebunan dan tanaman bahan makanan serta sektor peternakan. Keberhasilan pembangunan ekonomi di Kabupaten Merangin disumbangkan oleh sektor 
industri pengolahan dan konstruksi yang masing-masing sebesar 7,13 dan 7,01 persen (Badan Pusat Statistik Kabupaten Merangin, 2015).

Perkembangan struktur perekonomian di Kabupaten Merangin dapat dilihat dari tingkat pertumbuhan ekonomi. Data menunjukkan bahwa tingkat pertumbuhan ekonomi Kabupaten Merangin mencapai 6,95 persen per tahun selama periode 2011-2014 (Badan Pusat Statistik Kabupaten Merangin, 2015). Pertumbuhan ekonomi Kabupaten Merangin selama periode tersebut berfluktuatif, misalnya pada tahun 2011 tingkat pertumbuhan ekonomi sebesar 7,25 persen per tahun dan terjadi penurunan pada tahun 2012 hingga tahun 2013 dengan tingkat pertumbuhan sebesar 5,49 persen. Pertumbuhan ekonomi Kabupaten Merangin pada tahun 2014 kembali meningkat yaitu mencapai 6,95 persen per tahun (Tabel 1). Perkembangan pertumbuhan ekonomi tersebut mencerminkan bahwa fondasi ekonomi Kabupaten Merangin cukup kuat terutama pada sektor pertanian. Hasil penelitian ini sejalan dengan temuan Khairiyakh et al., (2015) bahwa hasil pertanian memberi kontribusi terhadap perekonomian Indonesia.

Tabel 1 Laju Pertumbuhan Ekonomi Kabupaten Merangin Menurut Lapangan Usaha

\begin{tabular}{clcccc}
\multicolumn{5}{c}{ Tahun 2011 - 2014 (\%) } \\
\multicolumn{7}{c}{ LAPANGAN USAHA } & $\mathbf{2 0 1 1}$ & $\mathbf{2 0 1 2}$ & $\mathbf{2 0 1 3}$ & $\mathbf{2 0 1 4}$ \\
\hline A & Pertanian, kehutanan, dan Perikanan & 5,69 & 6,56 & 5,17 & 6,32 \\
B & Pertambangan dan Penggalian & 23,49 & $-27,44$ & 0,71 & 8,87 \\
C & Industri Pengolahan & 10,76 & 7,97 & 8,45 & 5,46 \\
D & Pengadaan Listrik dan Gas & 12,11 & 8,53 & 9,55 & 8,43 \\
E & Pengadaan Air, Pengelolaan Sampah, & 6,36 & 2,53 & 1,5 & 2,79 \\
& Limbah dan Daur Ulang & & & & \\
F & Konstruksi & 5,71 & 16,85 & 13,19 & 7,56 \\
G & Perdagangan Besar dan Eceran; Reparasi & 9,18 & 8,3 & 8,12 & 9,09 \\
& Mobil dan Motor & & & & \\
H & Transportasi dan Pergudangan & 5,24 & 14,17 & 11,46 & 13,91 \\
I & Penyediaan Akomodasi makan dan Minum & 8,01 & 10,89 & 5,69 & 18,42 \\
J & Informasi dan Komunikasi & 6,09 & 7,08 & 4,42 & 5,32 \\
K & Jasa Keuangan dan Asuransi & 20,49 & 8,97 & 11,86 & 4,81 \\
L & Real Estat & 9,69 & 3,77 & 6,55 & 2,57 \\
M N & Jasa Perusahaan & 2,52 & 4,27 & 1,36 & 4,84 \\
O & Adm. Pemerintahan, Pertahanan dan Jaminan & 7,65 & 4,72 & 6,76 & 12,69 \\
& Sosial Wajib & & & & \\
P & Jasa Pendidikan & 3,46 & 5,99 & 6,2 & 0,12 \\
Q & Jasa Kesehatan dan Kegiatan Sosial & 4,45 & 8,03 & 7,7 & 16,65 \\
R,S,T, & Jasa Lainnya & 5,77 & 5,63 & 4,9 & 5,85 \\
U & $\quad$ & & & \\
\hline Produk Domestik Regional Bruto (PDRB) & $\mathbf{7 , 2 5}$ & $\mathbf{6 , 3 7}$ & $\mathbf{6 , 4 9}$ & $\mathbf{6 , 9 5}$ \\
\hline
\end{tabular}

Sumber: PDRB Kabupaten Merangin, 2014

Jika dilihat pola pertumbuhan ekonomi secara sektoral, terjadi peningkatan pertumbuhan yang fluktuatif dari suatu periode ke periode lainnya. Berdasarkan Tabel 1, tingkat pertumbuhan sektor pertambangan dan penggalian pada tahun 2011 sebesar 23,49 persen dan merupakan tingkat pertumbuhan tertinggi diantara sektor lainnya, namun pada tahun 2012 terjadi penurunan yang sangat signifikan yaitu menjadi -27,44 persen, sedangkan pada tahun 2014 kembali terjadi peningkatan sebesar 8,87 persen. Hal yang sama juga terjadi pada sektor jasa keuangan dan asuransi serta sektor perdagangan besar dan eceran yang menunjukkan tingkat pertumbuhan berfluktuatif selama periode tersebut. 
Namun demikian, tingkat pertumbuhan sektor pertanian selama periode 2011-2014 relatif stabil walaupun mengalami penurunan pada tahun 2013.

\section{Investasi dan Perekonomian Kabupaten Merangin}

Besaran modal yang akan diinvestasikan dalam proses produksi ditentukan oleh produktivitas marginal yang dibandingkan dengan tingkat hasil (output) yang diperoleh dengan menggunakan satu unit modal tambahan dalam proses produksi. Investasi akan terus dilakukan apabila produktivitas investasi masih lebih tinggi dibandingkan dengan tingkat bunga yang akan diterima jika modal itu dipinjamkan dan tidak diinvestasikan.

Berdasarkan harga konstan 2000, perkembangan nilai investasi di Kabupaten Merangin selama periode 2011-2014 mengalami peningkatan (Tabel 2) kecuali pada tahun 2014. Misal, pada tahun 2011 nilai investasi Pemerintah Kabupaten Merangin yang ditanamkan sebesar Rp. 2.633,23 juta, dan kemudian naik menjadi Rp. 5.395,99 juta pada tahun 2013, namun turun menjadi Rp.4.389,94 juta pada tahun 2014. Artinya, dari tahun 2011-2013 terjadi peningkatan investasi yang cukup signifikan dengan rata-rata sebesar 36,43 persen pada tahun 2012 dan terus meningkat hingga mencapai 50,19 persen. Penurunan investasi terjadi pada tahun 2014 yang mencapai 18,64 persen.

Tabel 2. Perkembangan Nilai Investasi di Kabupaten Merangin atas Dasar Harga Konstan 2000, 2011-2014 (Juta Rp.)

\begin{tabular}{clcccc}
\hline \multirow{2}{*}{ No } & \multicolumn{1}{c}{ Lapangan Usaha } & \multicolumn{4}{c}{ Jumlah Investasi } \\
\cline { 2 - 5 } & & $\mathbf{2 0 1 1}$ & $\mathbf{2 0 1 2}$ & $\mathbf{2 0 1 3}$ & $\mathbf{2 0 1 4}$ \\
\hline 1 & Pertanian, Peternakan, Kehutanan, & 917,48 & $1.312,04$ & $2.082,27$ & $1.685,35$ \\
& dan Perikanan & & & & \\
2 & Pertambangan dan Penggalian & 35,47 & 364,60 & 695,52 & 650,07 \\
3 & Industri Pengolahan & 479,44 & 665,45 & 870,66 & 675,12 \\
4 & Listrik, Gas, dan Air & 9,92 & 13,42 & 25,80 & 13,49 \\
5 & Konstruksi & 4,46 & 3,14 & 41,81 & 20,05 \\
6 & Perdagangan, Hotel dan Restoran & 894,00 & $1.055,48$ & $1.301,59$ & $1.232,67$ \\
7 & Pengangkutan dan Komunikasi & 9,63 & 12,35 & 129,20 & 12,27 \\
8 & Keugn, Real Estat, dan Jasa & 18,36 & 35,49 & 26,47 & 25,56 \\
& Perusahaan & & & & \\
9 & Jasa-jasa & 264,46 & 130,70 & 222,67 & 75,36 \\
\hline \multicolumn{2}{r}{ Jumlah Investasi } & $\mathbf{2 . 6 3 3 , 2 3}$ & $\mathbf{3 . 5 9 2 , 6 8}$ & $\mathbf{5 . 3 9 5 , 9 9}$ & $\mathbf{4 . 3 8 9 , 9 4}$ \\
\hline
\end{tabular}

Jika ditinjau menurut sektor ekonomi, selama periode 2011-2014 rata-rata investasi terbesar dilakukan pada sektor pertanian yaitu mencapai 34,84-38,59 persen, kemudian diikuti sektor perdagangan, perhotelan, dan restoran yaitu sekitar 24,12-33,95 persen, sedangkan empat sektor lainnya yang mempunyai rata-rata proporsi relatif kecil, yaitu sektor konstruksi, listrik, gas, dan air bersih, pengangkutan, serta sektor keuangan (Tabel 3).

Selanjutnya jika ditinjau menurut kelompok sektor selama periode pengamatan, rata-rata porsi investasi terbesar terjadi pada kelompok sektor primer (sektor pertanian) yaitu sebesar 39,09 persen, diikuti kelompok sektor tersier $(28,88$ persen) dan sektor sekunder (17,06 persen). Besarnya investasi pada sektor pertanian dalam pengembangan perekonomian di Kabupaten Merangin karena sektor pertanian sebagai lapangan usaha utama, sektor basis serta menyerap banyak tenaga kerja. Sektor pertanian merupakan sektor yang memiiki kontribusi terbesar pertama dalam penyerapan tenaga kerja yaitu mencapai 33,2 persen terhadap jumlah tenaga kerja yang ada di Indonesia (Widyawati, 
2017). Hasil temuan ini sejalan dengan penelitian Ardila (2012) di Kabupaten Banjarnegara bahwa sektor basis merupakan sektor dominan dan andalan untuk meningkatkan perekonomian daerah. Hasil penelitian terbaru juga di ditemukan oleh Sari (2018) studi di Kabupaten Kaur Provinsi Bengkulu melalui perhitungan nilai LQ, DLQ, dan nilai shift share bahwa sektor pertanian merupakan sektor basis dan unggulan.

Tabel 3. Perkembangan Nilai Investasi di Kabupaten Merangin atas Dasar Harga Berlaku, 2011-2014 (persen)

\begin{tabular}{clccccc}
\hline No & \multicolumn{1}{c}{ Lapangan Usaha } & $\mathbf{2 0 1 1}$ & $\mathbf{2 0 1 2}$ & $\mathbf{2 0 1 3}$ & $\mathbf{2 0 1 4}$ & Rerata \\
\hline 1 & Pertanian, Peternakan, & 34,84 & 36,52 & 38,59 & 38,39 & 37,09 \\
& Kehutanan dan Perikanan & & & & & \\
2 & Pertambangan dan Penggalian & 1,35 & 10,15 & 12,89 & 14,81 & 9,80 \\
3 & Industri Pengolahan & 18,21 & 18,52 & 16,14 & 15,38 & 17,06 \\
4 & Listrik, Gas dan Air & 0,38 & 0,37 & 0,48 & 0,31 & 0,38 \\
5 & Konstruksi & 0,17 & 0,09 & 0,77 & 0,46 & 0,37 \\
6 & Perdagangan, Hotel dan Restoran & 33,95 & 29,38 & 24,12 & 28,08 & 28,88 \\
7 & Pengangkutan dan Komunikasi & 0,37 & 0,34 & 2,39 & 0,28 & 0,85 \\
8 & Keuangan, Real Estat, dan Jasa & 0,70 & 0,99 & 0,49 & 0,58 & 0,69 \\
& Perusahaan & & & & & \\
9 & Jasa-jasa & 10,04 & 3,64 & 4,13 & 1,72 & 4,88 \\
\hline & $\quad$ Jumlah Investasi & $\mathbf{1 0 0 , 0 0}$ & $\mathbf{1 0 0 , 0 0}$ & $\mathbf{1 0 0 , 0 0}$ & $\mathbf{1 0 0 , 0 0}$ & $\mathbf{1 0 0 , 0 0}$ \\
& & $\mathbf{2 . 6 3 3 , 2}$ & $\mathbf{3 . 5 9 2 , 7}$ & $\mathbf{5 . 3 9 5 , 9}$ & $\mathbf{4 . 3 8 9 , 9}$ & \\
\hline
\end{tabular}

Jika investasi dilihat menurut pelaku usahanya, investasi swasta mencapai 61,21 persen dari total investasi di Kabupaten Merangin yang terdiri dari 35,58 persen dari swasta fasilitas PMA dan PMDN dan sebesar 38,79 persen dari swasta non fasilitas termasuk BUMN dan BUMD. Investasi oleh pemerintah hanya 1,06 persen pada tahun 2013 yang disusun oleh investasi oleh Pemerintah Daerah Kabupaten Merangin (Tabel $4)$.

Tabel 4. Distribusi Persentase Nilai Investasi Menurut Pelaku Usaha di Kabupaten Merangin, $2011-2014(\%)$

\begin{tabular}{|c|c|c|c|c|c|c|c|}
\hline No & Lapangan Usaha & UMKM & Pinjaman & PMA & PMDN & $\begin{array}{l}\text { Belanja } \\
\text { Modal }\end{array}$ & Total \\
\hline 1 & $\begin{array}{l}\text { Pertanian, Peternakan, } \\
\text { Kehutanan, dan } \\
\text { Perikanan }\end{array}$ & 29,29 & 33,72 & 19,67 & 17,06 & 0,26 & 100,00 \\
\hline 2 & $\begin{array}{l}\text { Pertambangan dan } \\
\text { Penggalian }\end{array}$ & 1,85 & 58,54 & 38,49 & 1,12 & - & 100,00 \\
\hline 3 & Industri Pengolahan & 0,61 & 0,62 & 19,93 & 78,84 & - & 100,00 \\
\hline 4 & Listrik, Gas dan Air & 0,84 & 0,84 & 1,48 & 84,79 & 12,04 & 100,00 \\
\hline 5 & Konstruksi & 45,07 & 45,29 & 0,00 & 0,00 & 9,65 & 100,00 \\
\hline 6 & $\begin{array}{l}\text { Perdagangan, Hotel, } \\
\text { dan Restoran }\end{array}$ & 45,74 & 49,64 & 4,44 & 0,15 & 0,03 & 100,00 \\
\hline 7 & $\begin{array}{l}\text { Pengangkutan dan } \\
\text { Komunikasi }\end{array}$ & 36,36 & 40,47 & 0,00 & 0,10 & 23,07 & 100,00 \\
\hline 8 & $\begin{array}{l}\text { Keuangan, Real Estat, } \\
\text { dan Jasa Perusahaan }\end{array}$ & 63,66 & 35,92 & 0,00 & 0,00 & 0,42 & 100,00 \\
\hline 9 & Jasa-jasa & 25,97 & 30,26 & 37,37 & 0,00 & 6,39 & 100,00 \\
\hline & Jumlah Investasi & 26,68 & 36,68 & 15,39 & 20,19 & 1,06 & 100,00 \\
\hline
\end{tabular}




\section{Angka ICOR Kabupaten Merangin \\ ICOR Total}

Berdasarkan Tabel 5, secara total nilai ICOR Kabupaten Merangin cukup baik yaitu memiliki nilai rata-rata 4,88. Artinya, untuk meningkatkan output satu unit diperlukan investasi sebesar 4,88 unit. Nilai investasi di Kabupaten Merangin mengalami fluktuatif dari tahun 2011 hingga tahun 2014, misalnya pada tahun 2011 nilai ICOR sebesar 3,20, kemudian pada tahun 2012 terjadi penurunan menjadi 3,17, dan pada tahun 2013 terjadi peningkatan cukup tajam yaitu mencapai 9,41, namun pada tahun 2014 kembali mengalami penurunan menjadi 3,73. Angka koefisien ICOR pada tahun 2013 yang mencapai 9,41 tersebut menunjukkan bahwa pada tahun tersebut banyak investasi yang dilakukan tetapi output yang dihasilkan hanya mengalami pertumbuhan positif yang relatif kecil.

Tabel 5. memperlihatkan bahwa sejak tahun 2011 hingga 2014 angka ICOR Kabupaten Merangin per tahun relatif tinggi yaitu di atas 3. Angka ICOR yang ideal secara teoritis berkisar (efisien) antara 3-4. Hal ini berarti kegiatan penanaman modal (investasi) yang dilakukan di Kabupaten Merangin dapat dikatakan relatif kurang efisien.

Berdasarkan data pada table 5, nilai ICOR sektor pertanian relative stabil yaitu berada pada angka 3-4 kecuali pada tahun 2013 bahwa nilai ICOR sektor pertanian mencapai angka 6,29. Hal ini mengindiaksikan bahwa sektor pertanian termasuk pada sektor yang tergolong efisien untuk dikembangkan pembanguan melalui investasi. Hal ini sejalan dengan penelitian Darsono \& Nurjayanti (2016) dan Tirani et al., (2018), besarnya dampak investasi terhadap perkeonomian daerah karena sektor pertanian sebagai sektor basis dan memiliki kontribusi yang besar terhadap pembangunam daerah.

Tabel 5. Distribusi Nilai ICOR Menurut Sektor di Kabupaten Merangin, 2011 - 2014

\begin{tabular}{|c|c|c|c|c|c|c|}
\hline No & Sektor & 2011 & 2012 & 2013 & 2014 & $\begin{array}{c}\text { ICOR } \\
\text { Rata-rata }\end{array}$ \\
\hline 1 & $\begin{array}{l}\text { Pertanian, Peternakan, } \\
\text { Kehutanan, dan Perikanan }\end{array}$ & 2,41 & 2,74 & 6,29 & 2,08 & 3,38 \\
\hline 2 & $\begin{array}{l}\text { Pertambangan dan } \\
\text { Penggalian }\end{array}$ & 0,40 & $-5,53$ & 34,29 & 13,73 & 10,72 \\
\hline 3 & Industri Pengolahan & 8,01 & 9,87 & 13,88 & 7,00 & 9,69 \\
\hline 4 & Listrik, Gas dan Air & 6,77 & 7,19 & 12,87 & 4,16 & 7,75 \\
\hline 5 & Konstruksi & 0,09 & 0,03 & 0,49 & 0,17 & 0,19 \\
\hline 6 & $\begin{array}{l}\text { Perdagangan, Hotel, dan } \\
\text { Restoran }\end{array}$ & 7,40 & 11,61 & 11,83 & 5,30 & 9,04 \\
\hline 7 & $\begin{array}{l}\text { Pengangkutan dan } \\
\text { Komunikasi }\end{array}$ & 0,22 & 0,19 & 1,62 & 0,11 & 0,53 \\
\hline 8 & $\begin{array}{l}\text { Keuangan, Real Estat, dan } \\
\text { Jasa Perusahaan }\end{array}$ & 0,37 & 0,95 & 0,49 & 0,68 & 0,62 \\
\hline 9 & Jasa-jasa & 3,16 & 1,48 & 2,89 & 0,34 & 1,97 \\
\hline & ICOR Total & 3,20 & 3,17 & 9,41 & 3,73 & 4,88 \\
\hline
\end{tabular}

Tabel 6. memperlihatkan bahwa angka koefisien ICOR pada tahun 2013 mencapai 9,41, namun pada tahun tersebut banyak investasi yang dilakukan tetapi output yang dihasilkan hanya mengalami pertumbuhan positif yang relatif kecil. Tahun 2013 merupakan periode pembangunan di Kabupaten Merangin sehingga diharuskan 
melakukan pembangunan baru di beberapa fasilitas publik dan infrastruktur lainnya atau perbaikan barang-barang modal tersebut. Maka dari itu, nilai investasi pada tahun tersebut relatif menjadi lebih besar namun produksi menurun karena belum pulihnya kapasitas produksi. Angka ICOR yang semakin baik pada tahun 2012 dan 2013 disebabkan karena barang modal dan peralatan yang terbatas pada tahun 2012 sudah dapat mulai berproduksi secara normal. Meskipun terjadi penurunan angka ICOR pada tahun 2013, angka ICOR Kabupaten Merangin masih relatif tinggi, yang menandakan proses produksi relatif belum efisien. Angka ICOR yang dianggap ideal (efisien) berada pada kisaran 3-4.

Tabel 6. Pertumbuhan Ekonomi dan ICOR Kabupaten Merangin Menurut Sektor Periode 2011-2014

\begin{tabular}{lcccccccc}
\hline \multirow{2}{*}{ Lapangan Usaha } & \multicolumn{4}{c}{ Pertumbuhan Ekonomi } & \multicolumn{4}{c}{ Nilai ICOR } \\
\cline { 2 - 8 } & $\mathbf{2 0 1 1}$ & $\mathbf{2 0 1 2}$ & $\mathbf{2 0 1 3}$ & $\mathbf{2 0 1 4}$ & $\mathbf{2 0 1 1}$ & $\mathbf{2 0 1 2}$ & $\mathbf{2 0 1 3}$ & $\mathbf{2 0 1 4}$ \\
\hline 1. Pertanian & 4,27 & 5,38 & 4,27 & 6,32 & 2,41 & 2,74 & 6,29 & 2,08 \\
2. Pertambangan \& & 18,28 & 0,57 & $(1,00)$ & 8,87 & 0,40 & $-5,53$ & 34,29 & 13,73 \\
$\quad$ Penggalian & & & & & & & & \\
3. Industri Pengolahan & 5,45 & 5,87 & 6,91 & 5,46 & 8,01 & 9,87 & 13,88 & 7,00 \\
4. Listrik, Gas \& Air Bersih & 9,69 & 9,79 & 6,82 & 4,08 & 6,77 & 7,19 & 12,87 & 4,16 \\
5. Konstruksi & 10,82 & 11,06 & 14,25 & 7,56 & 0,09 & 0,03 & 0,49 & 0,17 \\
$\begin{array}{l}\text { 6. Perdag., Hotel \& } \\
\quad \text { Restoran }\end{array}$ & 7,93 & 8,53 & 9,18 & 9,09 & 7,40 & 11,61 & 11,83 & 5,30 \\
$\begin{array}{l}\text { 7. Pengangkutan \& } \\
\quad \text { Komunikasi }\end{array}$ & 8,53 & 8,39 & 8,44 & 10,25 & 0,22 & 0,19 & 1,62 & 0,11 \\
$\begin{array}{l}\text { 8. Keuangan, Real Estat, \& } \\
\quad \text { Jasa Perusahaan }\end{array}$ & 9,18 & 11,11 & 8,48 & 3,51 & 0,37 & 0,95 & 0,49 & 0,68 \\
9. Jasa-Jasa & & & & & & & & \\
\hline \multicolumn{1}{c}{ PDRB } & 4,31 & 5,36 & 6,83 & 7,30 & 3,16 & 1,48 & 2,89 & 0,34 \\
\hline
\end{tabular}

\section{Hubungan ICOR dengan Pertumbuhan Ekonomi}

Koefisien korelasi antara ICOR total dengan laju pertumbuhan ekonomi dalam kurun waktu 10 tahun terakhir adalah sebesar $-0,922$ dan signifikan pada tingkat kesalahan kurang dari 1 persen (Tabel 7). Hal ini menunjukkan "hubungan yang terbalik" antara ICOR total dengan laju pertumbuhan ekonomi. Semakin tinggi pertumbuhan ekonomi semakin rendah nilai ICOR. Pada laju pertumbuhan yang lebih tinggi, diharapkan akan tercapai proses produksi yang lebih efisien.

Jika dilihat secara sektoral, sektor industri pengolahan mempunyai korelasi yang sangat kuat, yaitu 0,99 dan signifikan pada tingkat kesalahan kurang dari 1 persen. Kemudian, sektor yang tergolong kuat untuk menopang pertumbuhan ekonomi di kabupaten Merangin yaitu sektor pertanian, konstruksi, dan jasa-jasa yang mempunyai korelasi relatif kuat yaitu masing-masing $-0,58 ; 0,63$; dan 0,57 serta signifikan pada tingkat kesalahan kurang dari 5 persen. Besarnya kontribusi sektor pertanian terhadap pertumbuhan ekonomi karena sektor ini mampu menciptakan lapangan usaha dan kesempatan kerja. Lapangan usaha dan kesempatan kerja melalui sektor pertanian yaitu meliputi sub sektor perkebunan, tanaman pangan, hortikultura, dan susektor peternakan (Sari \& Herawaty, 2019). Sub sektor lain yang menjadi lapangan usaha yaitu Sub sektor tanaman bahan makanan dan hortikultura dan sub sektor peternakan termasuk dalam sub sektor maju (Widianingsih et al., 2015).

Disamping itu, sektor pertanian memiliki unggulan kompetitif karena sektor ini memiliki spesialisasi efek alokasi, memiliki nilai keterkaitan yang kuat dengan sktor lain, 
memiliki nilai positif dan menjadi daya ungkit terhadap pertumbuhan wilayah (Abidin, 2015).

Namun, sektor pertambangan dan penggalian, listrik, perdagangan, transportasi, dan keuangan mempunyai koefisien korelasi relatif kecil dan signifikan pada tingkat kesalahan kurang dari 10 persen. Koefisien korelasi yang negatif berarti semakin tinggi pertumbuhan ekonomi akan semakin rendah ICOR atau sebaliknya semakin rendah pertumbuhan ekonomi akan semakin tinggi ICOR.

Tabel 7. Koefisien Korelasi antara ICOR dan Pertumbuhan Ekonomi Sektoral di Kabupaten Merangin tahun 2013, dan 2014

\begin{tabular}{lcc}
\hline \multicolumn{1}{c}{ Sektor } & Koefisien Korelasi & Sig. \\
\hline \multicolumn{1}{c}{$(\mathbf{1})$} & $\mathbf{( 2 )}$ & $\mathbf{( 3 )}$ \\
\hline 1. Pertanian & $-0,58^{*}$ & 0,42 \\
2. Pertambangan \& Penggalian & $-0,42$ & 0,59 \\
3. Industri Pengolahan & $0,99^{* *}$ & 0,14 \\
4. Listrik, Gas \& Air Bersih & 0,18 & 0,82 \\
5. Konstruksi & $0,63^{*}$ & 0,38 \\
6. Perdag., Hotel \& Restoran & 0,13 & 0,87 \\
7. Pengangkutan \& Komunikasi & $-0,39$ & 0,61 \\
8. Keuangan, Real Estat, \& Jasa Perusahaan & 0,16 & 0,84 \\
9. Jasa-Jasa & $0,57^{*}$ & 0,43 \\
\hline \multicolumn{1}{c}{ PDRB } & $0,56^{*}$ & 0,44 \\
\hline
\end{tabular}

Keterangan: *korelasi kuat; ** korelasi sangat kuat

\section{ICOR Sektoral dan Tahunan}

ICOR tahunan dihitung dengan lag 0 artinya investasi yang ditanam pada tahun $\mathrm{t}$ akan menghasilkan nilai tambah pada tahun yang sama. Investasi yang dimaksud dalam penghitungan ini sudah mempertimbangkan perubahan inventori (Tabel 8). Hasil perhitungan menunjukkan bahwa angka ICOR Kabupaten Merangin bervariasi menurut sektor. Namun demikian, ada beberapa kecenderungan yang bisa diamati: Pertama, secara umum ICOR pada tahun 2013 mengalami peningkatan cukup signifikan yang mengindikasikan ekonomi Kabupaten Merangin semakin kurang efisien (Tabel 1.8). Tahun 2013, ICOR mencapai 9,41 dan menurun tajam hingga mencapai 3,73 pada tahun 2014. Hal tersebut berbanding terbalik dengan pertumbuhan ekonomi dari 6,45 persen pada tahun 2013 menjadi 6,95 persen pada tahun 2014. Angka ICOR yang sangat baik tersebut merupakan hasil dari upaya yang cukup keras pemerintah daerah dalam merencanakan dan mengimplementasikan pembangunan disamping kondisi makro ekonomi perekonomian nasional dan regional yang semakin kondusif sehingga perekonomian Kabupaten Merangin mampu tumbuh cukup baik.

Kedua, sektor pertanian, konstruksi, pengangkutan dan komunikasi, keuangan, dan sektor jasa-jasa mempunyai ICOR relatif lebih baik dibanding sektor lainnya. Angka ICOR yang rendah untuk sektor pertanian disebabkan oleh proses produksi yang pendek dan kecilnya proporsi investasi dibanding biaya antara (intermediate cost) dalam struktur ongkos usaha taninya. Angka ICOR yang rendah untuk sektor konstruksi, pengangkutan dan komunikasi, keuangan, dan sektor jasa-jasa disebabkan oleh perputaran modal yang cepat dan proses porduksi yang sangat pendek khususnya subsektor jasa-jasa. Ketiga, sektor pertambangan, industri pengolahan, listrik dan air bersih, dan sektor perdagangan mempunyai ICOR relatif tinggi, hal ini berkaitan erat dengan karakter sektor tersebut 
yang bersifat padat modal dan investasinya bersifat jangka panjang terutama sektor pertambangan dan listrik.

Tabel 8. ICOR Sektoral Tahunan Kabupaten Merangin Metode Standar Lag 0, 2011-2014

\begin{tabular}{lcccc}
\hline \multicolumn{1}{c}{ Sektor } & $\mathbf{2 0 1 1}$ & $\mathbf{2 0 1 2}$ & $\mathbf{2 0 1 3}$ & $\mathbf{2 0 1 4}$ \\
\hline \multicolumn{1}{c}{$(\mathbf{1})$} & $\mathbf{( 2 )}$ & $\mathbf{( 3 )}$ & $\mathbf{( 4 )}$ & $\mathbf{( 5 )}$ \\
\hline 1. Pertanian & 2,41 & 2,74 & 6,29 & 2,08 \\
2. Pertambangan \& Penggalian & 0,40 & $-5,53$ & 34,29 & 13,73 \\
3. Industri Pengolahan & 8,01 & 9,87 & 13,88 & 7,00 \\
4. Listrik, Gas \& Air Bersih & 6,77 & 7,19 & 12,87 & 4,16 \\
5. Konstruksi & 0,09 & 0,03 & 0,49 & 0,17 \\
6. Perdagangan, Hotel, \& Restoran & 7,40 & 11,61 & 11,83 & 5,30 \\
7. Pengangkutan \& Komunikasi & 0,22 & 0,19 & 1,62 & 0,11 \\
8. Keuangan, Real Estat, \& Jasa Perusahaan & 0,37 & 0,95 & 0,49 & 0,68 \\
9. Jasa-Jasa & 3,16 & 1,48 & 2,89 & 0,34 \\
\hline \multicolumn{1}{c}{ PDRB } & $\mathbf{3 , 2 0}$ & $\mathbf{3 , 1 7}$ & $\mathbf{9 , 4 1}$ & $\mathbf{3 , 7 3}$ \\
\hline
\end{tabular}

\section{Kontribusi Sektor Pertanian terhadap Perekonomian dan Pilihan Investasi}

Angka ICOR yang digunakan disini adalah hasil perhitungan ICOR dengan metode standar untuk periode 2011-2014 dengan pendekatan investasi sama dengan PMTB plus perubahan inventori (lihat Tabel 8). Pertanyaan penting yang harus dijawab adalah pada sektor apa saja sebaiknya investasi dilakukan. Apakah pilihan investasi dilakukan dengan indikator tunggal berupa ICOR atau perlu dipertimbangkan dalam menentukan pilihan investasi. Pertama, sektor dengan koefisien ICOR kecil seharusnya mendapat prioritas untuk dilakukan investasi, karena dari segi ekonomi sektor ini menunjukkan tingkat efisiensi yang lebih tinggi. Kedua, sektor-sektor yang mempunyai serapan tenaga kerja yang besar meskipun mempunyai angka ICOR yang relatif tinggi perlu mendapat prioritas investasi. Ketiga, sektor-sektor yang mempunyai backward and forward linkages tinggi perlu dipertimbangkan untuk mendapat prioritas investasi karena mempunyai multiplier effect yang relatif lebih luas. Selain itu, pilihan investasi juga harus mempertimbangkan kepemilikan sumber daya (resource endowments) dari daerah setempat, kebijakan pemerintah mengenai konservasi sumber daya alam, dan faktor lainnya.

Jika dilihat dari besaran ICOR, maka sektor pertanian merupakan sektor ekonomi yang mempunyai ICOR relatif rendah (lebih efisien). Artinya, sektor pertanian mampu memberikan kontribusi atau nilai tambah terhadap pengembangan pembangunan ekonomi di Kabupaten Merangin. Besarnya kontribusi sektor pertanian terhadap perekonomian daerah karena sektor pertanian tergolong sektor prima dan potensial (Rizani, 2017) serta sektor basis (Pantow et al., 2015; Rauna, 2015; Silaban et al., 2015). Menurut hasil penelitian (Erna et al., 2018), sub sektor pertanian yang memberi kontribusi dalam perekonomian wilayah yaitu sub sektor tanaman bahan makanan, perkebunan, peternakan, kehutanan, dan sub sektor perikanan. Besarnya kontribusi komoditas tanaman pangan terhadap perekonomian wilayah karena komoditas tanaman pangan sebagai komoditas basis (Qomariyah et al., 2018).

Kemudian, sektor pertanian memiliki dampak pengganda yang relatif tinggi (multiplier effects) terhadap sektor primer lainnya, sektor sekunder, dan sektor tersier. Hasil penelitian ini sejalan dengan penelitian Widyawati (2017), sektor pertanian 
memiliki nilai keterkaitan ke depan (forward linkages)secara langsung secara signifikan terhadap sektor listrik, gas, dan air bersih, sektor pertambangan dan penggalian; sektor keuangan, persewaan, jasa perusahaan; sektor perdagangan, hotel, dan restoran. Kemudian, sektor pertanian juga memiliki nilai keterkaitan ke belakang (backward linkages) secara langsung yang tinggi terhadap sektor bangunan; sektor industri pengolahan; dan sektor pengangkutan dan komunikasi.

Berdasarkan beberapa indikator tersebut maka prioritas utama investasi di Kabupaten Merangin pada sektor pertanian terutama subsektor perkebunan dan subsektor tanaman pangan. Hal ini karena sektor pertanian mempunyai ICOR terendah dan serapan tenaga kerja yang tinggi serta kepemilikan sumber daya lahan dan air yang relatif memadai di Kabupaten Merangin. Prioritas investasi selanjutnya adalah sektor industri pengolahan, dengan nilai ICOR relatif rendah dan mempunyai serapan tenaga kerja yang tinggi. Sektor yang bisa menjadi prioritas investasi lainnya adalah sektor jasa-jasa, karena mempunyai serapan tenaga kerja yang cukup tinggi dan mempunyai angka ICOR yang relatif tinggi.

Sektor-sektor lain yang memiliki nilai ICOR yang relatif rendah yaitu sektor konstruksi, pengangkutan dan komunikasi, keuangan, dan sektor jasa-jasa merupakan sektor-sektor ekonomi yang mempunyai ICOR relatif rendah (lebih efisien), sedangkan sektor pertambangan, industri pengolahan, perdagangan, dan listrik dan air bersih merupakan sektor-sektor dengan perolehan ICOR relatif tinggi, yang berarti relatif kurang efisien. Jika dilihat dari serapan tenaga kerja, maka sektor perdagangan, industri, dan jasa-jasa merupakan sektor-sektor dengan kemampuan serapan tenaga kerja yang relatif cukup tinggi.

Sektor pertambangan dan industri pengolahan yang memiliki nilai ICOR yang relatif tinggi, tidak direkomendasikan untuk menjadi pilihan prioritas investasi karena Kabupaten Merangin tidak menonjol dalam kepemilikan sumber daya alam tambang dan mineral. Oleh sebab itu diperlukan upaya bersama untuk melindungi lahan pertanian dan daerah aliran sungai (DAS) dari kerusakan lingkungan dan pencemaran (polusi). Sektor listrik dan air bersih juga bukan merupakan pilihan prioritas investasi yang urgent karena selain angka ICOR yang relatif tinggi, juga lebih bersifat capital intensive, sedangkan jika dilihat dari skala usaha, pilihan investasi sebaiknya dilakukan pada skala usaha mikro dan kecil (UMK). Hal ini karena dari hasil Sensus Ekonomi 2013 Kabupaten Merangin mayoritas merupakan usaha mikro.

\section{KESIMPULAN}

Berdasarkan hasil analisis dapat disimpulkan bahwa selama periode 2011-2014, investasi terbesar dilakukan pada sektor pertanian yaitu mencapai 37,45 persen, kemudian diikuti sektor perdagangan dan sektor industri pengolahan, masing-masing 28,00 dan 16,80 persen, sedangkan empat sektor lainnya mempunyai investasi terkecil yaitu sektor listrik dan air bersih; sektor konstruksi; pengangkutan dan komunikasi; dan sektor keuangan, masingmasing 0,$39 ; 0,43 ; 1,02$; dan 0,66 persen. Besarnya investasi pada sektor pertanian dalam pengembangan perekonomian di Kabupaten Merangin karena sektor pertanian merupakan lapangan usaha utama, sektor basis serta menyerap banyak tenaga kerja.

Hasil analisis menunjukkan bahwa rata-rata angka ICOR pada periode 2010-2014 sebesar 9.41. Nilai ICOR tahun 2015 lebih baik dari nilai ICOR tahun sebelumnya. Sektor pertanian memiliki ICOR terendah dan diikuti sektor pengangkutan; konstruksi; keuangan; dan sektor jasa, sedangkan sektor pertambangan; industri pengolahan; listrik, dan sektor perdagangan memiliki nilai ICOR tertinggi. Berdasarkan nilai ICOR tersebut, sektor pertanian memiliki dampak positif dan efisien dalam berinvestasi. Artinya, sektor pertanian 
mampu memberikan kontribusi atau nilai tambah terhadap pengembangan pembangunan ekonomi di Kabupaten Merangin. Kemudian, sektor pertanian memiliki dampak pengganda yang relatif tinggi (multiplier effects) terhadap sektor primer lainnya, sektor sekunder, dan sektor tersier.

\section{DAFTAR PUSTAKA}

Abidin, Z. (2015). Aplikasi Analisis Shift Share pada Transformasi Sektor Pertanian dalam Perekonomian Wilayah di Sulawesi Tenggara. Informatika Pertanian, 24(2), 165-178.

Ardila, R. (2012). Analisis Pengembangan Pusat Pertumbuhan Ekonomi di Kabupaten Banjarnegara. Economics Development Analysis Journal, 2, 1-9.

Badan Pusat Statistik dan Badan Perencanaan Pembangunan Derah Daerah Istimewa Yogyakarta. (2013). Analisis ICOR Sektoral Daerah Istimewa Yogyakarta 20092013.

Badan Pusat Statistik Indonesia. (2019). Keadaan Ketenagakerjaan Indonesia (Issue 41).

Badan Pusat Statistik Kabupaten Merangin. (2015). Produk Domestik Regional Bruto Kabupaten Merangin menurut Lapangan Usaha 2010-2014.

Badan Pusat Statistik Provinsi Jambi. (2015). Tabel-tabel Pokok Produk Domestik Regional Bruto (PDRB) Provinsi Jambi menurut Lapangan Usaha dan menurut Penggunaan Tahun 2010-2014. Badan Pusat Statistik Provinsi Jambi.

Darsono, H. W., \& Nurjayanti, E. D. (2016). Identifikasi Posisi dan Kontribusi Sektor Pertanian dalam Perekonomian Daerah di Kabupaten Temanggung. MEDIAGRO, 12(1), 17-26.

Erna, F., Harisudin, M., \& Rahayu, W. (2018). Analisis Peran Subsektor Pertanian Terhadap Pembangunan Kabupaten Karanganyar; Sebuah Pendekatan Comparative Performance Index. SEPA: Jurnal Sosial Ekonomi Pertanian Dan Agribisnis, 14(1), 28-38. https://doi.org/10.20961/sepa.v14i1.21040

Khairiyakh, R., Irham, I., \& Mulyo, J. H. (2015). Contribution of Agricultural Sector and Sub Sectors on Indonesian Economy. Ilmu Pertanian (Agricultural Science), 18(3), 150-159. https://doi.org/10.22146/ipas.10616

Pantow, S., Palar, S., \& Wauran, P. (2015). Analisis Potensi Unggulan dan Daya Saing Sub Sektor Pertanian di Kabupaten Minahasa. Jurnal Berkala Ilmiah Efisiensi, 15(04), 100-112.

Qomariyah, S., Mustapit, \& Supriono, A. (2018). Analisis Potensi Wilayah Berbasis Komoditas Pertanian Tanaman Pangan serta Kontribusinya terhadap Perekonomian Kabupaten Bondowoso. Journal of Social and Agricultural Economic, 11(1), 66-72.

Rauna, U. (2015). Analisis Sektor Basis Dan Subsektor Basis Pertanian. Journal of Social and Agricultural Economic, 8(3), 10-21.

Rizani, A. (2017). Analisis Potensi Ekonomi di Sektor dan Subsektor Pertanian, Kehutanan, dan Perikanan Kabupaten Jember. Jurnal Ekonomi Pembangunan, 15(2), 137-156.

Sari, F. W. A. W., \& Herawaty, B. R. (2019). Analisis Peranan Sektor Pertanian, 
Kehutanan dan Perikanan pada Perekonomian Kabupaten Deli Serdang. Journal Agroland, 26(3), 198-211.

Sari, S. R. (2018). Kontribusi Sektor Pertanian Dalam Struktur Ekonomi Di Kabupaten Kaur Provinsi Bengkulu. Jurnal AGRISEP: Kajian Masalah Sosial Ekonomi Pertanian Dan Agribisnis, 17(2), 175-186. https://doi.org/10.31186/jagrisep.17.2.175-186

Sayifullah, \& Emmalian. (2018). Pengaruh Tenaga Kerja Sektor Pertanian Dan Pengeluaran Pemerintah Sektor Pertanian Terhadap Produk Domestik Bruto Sektor Pertanian Di Indonesia. Jurnal Ekonomi-Qu, 8(1), 66-81. https://doi.org/10.35448/jequ.v8i1.4962

Silaban, L., Edwina, S., \& Eliza. (2015). Analisis Sektor Basis dan Perkembangan Sektor Pertanian di Kabupaten Indragiri Hilir Provinsi Riau Tahun 2008-2012. Jom Pertanian, 2(1).

Sulistiawati, R. (2012). Pengaruh Investasi terhadap Pertumbuhan Ekonomi dan Penyerapan Tenaga Kerja Serta Kesejahteraan Masyarakat di Provinsi di Indonesia. Jurnal Ekonomi, Bisnis Dan Kewirausahaan Untan, 3(1), 29-50.

Tirani, T., Pranoto, Y. S., \& Moelyo, H. (2018). Kontribusi Sektor Pertanian berdasarkan Keunggulan Wilayah di Kabupaten Bangka. Caraka Tani: Journal of Sustainable Agriculture, 33(1), 42-49. https://doi.org/10.20961/carakatani.v33i1.19662

Widianingsih, W., Suryantini, A., \& Irham. (2015). Kontribusi Sektor Pertanian pada Perrtumbuhan Ekonomi di Provinsi Jawa Barat. Agro Ekonomi, 26(2), 206-281.

Widyawati, R. F. (2017). Analisis Keterkaitan Sektor Pertanian dan Pengaruhnya Terhadap Perekonomian Indonesia (Analisis Input Output). Economia, 13(1), 1427. 